\section{Induced Polyploidy in Diploid Ornamental Ginger (Hedychium muluense R. M. Smith) Using Colchicine and Oryzalin}

\author{
Hamidou F. Sakhanokho ${ }^{1}$ \\ USDA, ARS, 810 Hwy 26 West, P.O. Box 287, Poplarville, MS 39470
}

Kanniah Rajasekaran

USDA-ARS-SRRC, 1100 Robert E. Lee Boulevard, New Orleans, LA 70124

Rowena Y. Kelley

Department of Biochemistry and Molecular Biology, Mississippi State

University, P.O. Box 9650, Mississippi State, MS 39762

Nurul Islam-Faridi

Southern Institute of Forest Genetics, Southern Research Station, U.S. Forest Service, Department of Ecosystem Science and Management, TAMU-2585, Texas A\&M University, College Station, TX 77843-2585

Additional index words. ornamental ginger, flow cytometry, chromosome count, chloroplast frequency, stomatal frequency, stomatal length

\begin{abstract}
The ploidy level of $H$. muluense, a diploid $(2 n=2 x=34)$ and dwarf ornamental ginger species, has been determined and is reported for the first time. Oryzalin and colchicine were successfully used to induce polyploidy in Hedychium muluense in vitro. Embryogenic cell lines were treated with oryzalin $(30,60$, or $120 \mu M)$ and colchicine $(2.5,5$, or $10 \mathrm{~mm})$ for 24,48 , or $72 \mathrm{~h}$. The control contained no antimitotic agent. Flow cytometry, chloroplast count, and stomatal frequency were more effective and reliable than stomatal length as methods for assessing ploidy. Overall, oryzalin was more effective than colchicine in inducing polyploidy. The highest induction frequency $(15 \%)$ of tetraploidy was achieved when embryogenic callus was exposed to $60 \mu M$ oryzalin for $72 \mathrm{~h}$. For colchicine, exposure of embryogenic callus to the $2.5 \mathrm{~mm}$ colchicine for $24 \mathrm{~h}$ was the most effective in creating tetraploid (13\%) plants.
\end{abstract}

Hedychium J. Koenig is one of the largest genera of the Zingiberaceae with close to 80 species (Gopanraj et al., 2005; Wood et al., 2000). As an ornamental, it is cultivated for its sweet-scented flowers and attractive green foliage. Hedychium plants are also used in perfumery and in ethnomedicine (Gao et al., 2008; Gopanraj et al., 2005). Most Hedychium species are diploid $(2 n=2 x=34)$, but triploids $(2 n=3 x=51)$, tetraploids $(2 n=4 x=68)$ as well as aneuploids exist both at interspecific and intraspecific levels (Eksomtramage et al., 2002; Mukherjee, 1970; Raghavan and Venkatasubban, 1943; Sharma and Bhattacharyya, 1958). Induced polyploidy is a valuable tool that offers some benefits for horticultural, pharmaceutical, and agricultural improvement of plants (Ascough et al., 2008). For instance, increased ploidy level was associated with increased flower size in rhododendrons and

Received for publication 22 June 2009. Accepted for publication 24 Aug. 2009.

We thank Kermis Myrick, Alexandria Goins, Tigest Boutwell, and Ramata Sakhanokho for technical assistance.

${ }^{1}$ To whom reprint requests should be addressed; e-mail Hamidou.Sakhanokho@ars.usda.gov. intensified flower colors in carnation and cyclamen (Takamura and Miyajima, 1996; Yamaguchi, 1989). Induced polyploidy can also remove hybridization barriers resulting from differences in ploidy levels (RissoPascotto et al., 2005).

Induced polyploidy has been achieved in several plant species using the antimitotic chemicals colchicine and oryzalin (Dhooghe et al., 2009; Pickens et al., 2006; Rey et al., 2002). Colchicine binds poorly to plant tubulins but has a high affinity for animal microtubulins and thus is toxic to humans (Morejohn et al., 1987). By contrast, oryzalin specifically binds to plant tubulins, so it can be used at lower concentrations (Bajer and Molè-Bajer, 1986; Lehrer et al., 2008). To verify the ploidy level of treated plants, several techniques are available, including the count of chromosome and chloroplast number, the measure of stomatal length and frequency, and flow cytometry. Although chromosome counts may be the most accurate technique for ploidy determination, this method is often time-consuming and very tedious, especially for plant species such as Hedychium with small meristematic cells and dense cytoplasm containing large numbers of chromosomes (Sharma and Bhattacharyya,
1958). Flow cytometry equipment is expensive, but chromosome analysis through flow cytometry is a quick, reproducible, and dependable method and particularly suited for determining the ploidy levels of large numbers of samples. Flow cytometry has been used extensively to determine the ploidy levels in several plant species (Bonos et al., 2002; Dansi et al., 2001). Stomatal frequency and length and chloroplast number per pair of guard cells also have been used as indirect methods for assessing the plant ploidy levels (Beck et al., 2003; Sari et al., 1999; Singsit and Ozias-Akins, 1992; Singsit and Veilleux, 1991). Therefore, in the absence of flow cytometry, these methods could be used to assess ploidy. Stomatal frequency was negatively correlated with ploidy level in Bromus inermis Leyss, but stomatal length increased as ploidy increased (Aryavand et al., 2003; Rajendra et al., 1978; Tan and Dunn, 1973). Chloroplast frequency in guard cells was positively correlated with ploidy in several plant species (Sari et al., 1999; Singsit and Ozias-Akins, 1992; Singsit and Veilleux, 1991).

One of the traits that limits the use of Hedychium species and cultivars as potted plants is their considerable height. However, $H$. muluense, whose diploid $(2 n=2 x=34)$ status was determined in the current study, is a dwarf $(\approx 2$ feet or $0.60 \mathrm{~m})$ species with small but beautiful flowers. Introgression of the dwarf trait into some of the more ornamentally desirable species or cultivars is a desirable goal, but hybridization barriers resulting from differences in ploidy could hinder this goal. Therefore, the purpose of this study was to induce polyploidy, particularly tetraploidy in $H$. muluense using colchicine and oryzalin.

\section{Materials and Methods}

Tissue culture. Seeds of Hedychium muluense were collected from greenhousegrown plants, surface-sterilized, and germinated following a protocol described by Sakhanokho et al. (2008). Also, callus and embryos were induced following a protocol described by the same authors. Leaf explants were removed from 5- to 7-d-old in vitro germinated seedlings, cut into 3- to 4- $\mathrm{mm}$ segments, and transferred to $100 \mathrm{~mm} \times 20-\mathrm{mm}$ petri dishes containing callus initiation and proliferation medium consisting of Murashige and Skoog (MS) basal salts supplemented with $9.05 \mu \mathrm{M} 2,4-\mathrm{D}$ and $4.6 \mu \mathrm{M}$ kinetin. To induce somatic embryogenesis, friable callus was transferred to a liquid medium containing MS basal salts, B5 vitamins, $0.6 \mu \mathrm{M}$ thidiazuron, $8.9 \mu \mathrm{M}$ 6-benzylaminopurine, $20 \mathrm{~g} \cdot \mathrm{L}^{-1}$ sucrose, $0.2 \mathrm{~g} \cdot \mathrm{L}^{-1}$ myo-inositol, $1 \mathrm{~g} \cdot \mathrm{L}^{-1}$ casein hydrolysate, and $1 \mathrm{mg} \cdot \mathrm{L}^{-1}$ thiamine. Colchicine (MP Biomedicals, Irvine, CA) and oryzalin (ChemService, West Chester, PA) were filter-sterilized through a $0.22-\mu \mathrm{m}$ filter (Corning Inc., Corning, NY) and then added to the autoclaved media. A 1\% filter-sterilized dimethyl sulfoxide (Sigma, St. Louis, MO) solution was added to each antimitotic 
agent-containing media as well as the controls. The effects of various concentrations of colchicine $(2.5,5,10 \mathrm{~mm})$ and oryzalin $(30,60$, $120 \mu \mathrm{M}$ ) applied to these cultures for varying durations $(24,48,72 \mathrm{~h})$ were evaluated. The cultures were then transferred to $100 \mathrm{~mm} \times 20$ $\mathrm{mm}$ petri dishes containing a solid medium similar to the liquid medium described previously but also including $0.75 \mathrm{~g} \cdot \mathrm{L}^{-1} \mathrm{MgCl}_{2}$ and $2 \mathrm{~g} \cdot \mathrm{L}^{-1}$ Gelrite (Sigma). The cultures were then sealed with Parafilm ${ }^{\circledR}$ (Fisher Scientific, Atlanta, GA) and incubated at $22^{\circ} \mathrm{C}$ and $16-\mathrm{h}$ light $\left(100 \mu \mathrm{mol} \cdot \mathrm{m}^{-2} \cdot \mathrm{s}^{-1}\right) / 8-\mathrm{h}$ dark period. Rooting and plantlet acclimatization were performed following a protocol described by Sakhanokho et al. (2008).

Experimental design and statistical analysis. Two separate experiments were conducted to evaluate the effect of two antimitotic inhibitors in inducing polyploidy in $H$. muluense. The first experiment was a factorial arrangement of three concentrations of colchicine $(2.5,5$, or $10 \mathrm{~mm})$ and three durations $(24,48$, or $72 \mathrm{~h}$ ) and the second one a factorial arrangement of three concentrations of oryzalin $(30,60$, or $120 \mu \mathrm{M})$ and three durations $(24,48$, or $72 \mathrm{~h})$. The experiment was repeated twice at different times. The controls contained no antimitotic inhibitor. In each replication, there were five flasks per treatment and per duration. The flasks were placed on an orbital shaker at $22^{\circ} \mathrm{C}$ and agitated at $110 \mathrm{rpm}$. The liquid medium was drained out of each flask and the content was subsequently transferred and distributed among $20100 \mathrm{~mm} \times 20$-mm petri dishes containing the solid embryo initiation medium. Approximately $0.75 \mathrm{~g}$ of embryogenic callus was transferred in each plate. There were 20 plates per treatment and per duration. Cultures were transferred to fresh media every 4 weeks. Rate of callus growth after 4 weeks was measured and embryos per gram of callus counted after $60 \mathrm{~d}$. Analysis of variance (ANOVA) and Pearson's correlation coefficients were used to analyze data using SAS Institute (2003) software.

Chromosome preparation and microscopy. Actively growing root tips $(\approx 1 \mathrm{~cm}$ long) were harvested from $H$. muluense plants growing in potting soil in a greenhouse and immediately pretreated with an aqueous solution of $\alpha$ bromo-naphthalene $(0.8 \%)$ for $3.5 \mathrm{~h}$ in the dark at room temperature followed by fixing in a 4:1 (95\% ethanol:glacial acetic acid) solution to arrest the cell division at metaphase. Fixed root tips were processed enzymatically ( $5 \%$ cellulase (v/v; Sigma), 20\% pectinase (v/v; Sigma), 5\% cellulose (Serva Electrophoresis, Germany), 1\% cellulose RS (Yakult Pharmaceutical Ind. Co. Ltd., Japan), and $1 \%$ pectolyase Y-23 (Kyowa Chemical Products Co. Ltd., Japan) in $0.01 \mathrm{M}$ citrate buffer and the chromosome spreads were prepared on to ethanol (95\%) -washed glass slides as described elsewhere (Jewel and Islam-Faridi, 1994). The preparations were counterstained with $02 \%$ Azure B. Digital images were recorded from an AxioImager Z-1 transmitted light microscope using a COHU high Performance CCD Camera (MetaSystem Inc.). Im- ages were processed with Adobe Photoshop CS v8 (Adobe Systems).

Ploidy analysis through flow cytometry. Ploidy levels were determined for young, unexpanded leaf tissues from colchicineand oryzalin-treated plants using a Partec Ploidy Analyzer (Partec, Muenster, Germany). A piece of leaf tissue $\approx 1 \mathrm{~cm}^{2}$ was chopped with a double-edged razor blade in a petri dish containing nuclei extraction buffer. Buffers were supplied as part of the Cystain ultraviolet Precise P Staining Kit (Partec, Muenster, Germany). After a 30-s incubation period with gentle agitation, the extract was poured through a $50-\mu \mathrm{m}$ mesh sieve. DNA fluorochrome, 4'-6 diamidino-2-phenylindole (Partec), nucleus staining buffer was added to the extract buffer in a ratio of $3: 1$ and the sample was analyzed immediately for the DNA content of the nuclei. Sample measurements were replicated three times for each plant. Results were displayed as histograms showing the number of nuclei grouped in peaks of relative fluorescence intensity, which is proportional to DNA content. To determine the standard peak of diploid cells (2C DNA), leaf tissues were collected from nontreated control plants. Instrument gain was adjusted so that the peak of nuclei isolated from nontreated control plants was set at channel 50, and this calibration was checked periodically to minimize variation resulting from runs. Therefore, peaks representing nuclei from samples with diploid, triploid, and tetraploid levels were expected at channels 50, 75, and 100, respectively.

Evaluation of stomatal frequency and length. The adaxial leaf surface has a significantly higher stomatal frequency and less variation than the abaxial surface of the leaves (Rajendra et al., 1978; Teare et al., 1971). Preliminary results obtained in our laboratory, which showed that adaxial leaves of Hedychium muluense have more stomata than their abaxial leaves, confirmed these findings. Therefore, for stomatal counts, only the adaxial surface of the leaves was used in this study. Three leaf samples from each plant were analyzed. The number of stomata was counted from three different microscopic fields of view for each leaf sample using a light microscope (ACCU-SCOPE, Inc., Sea Cliff, NY) at $10 \times$ magnification, and the number of stomata per field of view was converted to stomata per square millimeter.

For stomatal length measurements, three leaf samples $\left(\approx 0.50 \mathrm{~cm}^{2}\right.$ each) were collected from each plant using a \#3 hole puncher (Fisher Scientific, Atlanta, GA). The samples were placed in $13-\mathrm{mL}$ tubes, and a $40 \%$ nitric acid solution was added to cover the leaf pieces. The tubes were placed in a $90{ }^{\circ} \mathrm{C}$ water bath for $15 \mathrm{~min}$. Every $5 \mathrm{~min}$, the tubes were shaken two times during heating to separate the top and bottom layers of each sample. At the end of the 15-min heating process, the tubes were removed, shaken for $2 \mathrm{~min}$ again, and the acid poured off, then leaf sections were rinsed with deionized water. A $1 \mathrm{~N}$ sodium hydroxide (Sigma, St. Louis, MO) was added to cover the leaf samples for $10 \mathrm{~min}$. Afterward, the sodium hydroxide was poured off and leaf samples were rinsed with deionized water. Samples were subsequently covered with toluidine blue stain (Fisher, Fair Lawn, NJ) and allowed to sit for $1 \mathrm{~h}$. The stain was then poured off and the leaf samples were rinsed with deionized water. Then samples were rinsed successively with $50 \%, 70 \%, 80 \%$, and $95 \%$ ethanol and covered with $100 \%$ ethanol (Fisher) and stored until needed. Leaf samples were placed on slides and covered with a coverslip. Five stomata from each plant sample were viewed under an ACCU-SCOPE microscope (ACCUSCOPE, Inc., Sea Cliff, NY) at $1000 \times$ oil immersion magnification. The stomata were photographed with an M Eye Digital camera (Ken-A-Vision, Kansas City, MO), and the stomatal length was measured using Vision Explore software (Ken-A-Vision).

Chloroplast counts. Three leaf sections were from each plant were analyzed. The top mesophyll tissues were removed using a scalpel, leaving the lower epidermis. This section was placed on a slide with a drop of deionized water. A coverslip was placed on the slide and observed at $1000 \times$ under an Olympus BX 60 fluorescent microscope equipped with a fluorescein isothiocynate filter. After a few seconds, chloroplasts could be counted when they began to glow. The chloroplasts were

Table 1. Callus growth (\%) and number of somatic embryos/g callus (SEs/g) from Hedychium muluense callus exposed to various concentrations of colchicine for various durations. ${ }^{z}$

\begin{tabular}{lccc}
\hline Concn $(\mathrm{mm})$ & Exposure time $(\mathrm{h})$ & Percent callus growth $^{\mathrm{y}}$ & Number of SEs/g callus $^{\mathrm{y}}$ \\
\hline 0 & 24 & $397.2 \mathrm{a}$ & $81.5 \mathrm{a}$ \\
0 & 48 & $396.2 \mathrm{a}$ & $77.7 \mathrm{a}$ \\
0 & 72 & $391.3 \mathrm{a}$ & $78.7 \mathrm{a}$ \\
2.5 & 24 & $474.6 \mathrm{a}$ & $81.7 \mathrm{a}$ \\
2.5 & 48 & $481.6 \mathrm{a}$ & $87.6 \mathrm{a}$ \\
2.5 & 72 & $495.5 \mathrm{a}$ & $71.0 \mathrm{a}$ \\
5 & 24 & $341.8 \mathrm{a}$ & $66.3 \mathrm{a}$ \\
5 & 48 & $341.8 \mathrm{a}$ & $65.1 \mathrm{a}$ \\
5 & 72 & $279.7 \mathrm{~b}$ & $65.2 \mathrm{a}$ \\
10 & 24 & $181.7 \mathrm{a}$ & $65.2 \mathrm{a}$ \\
10 & 48 & $191.7 \mathrm{a}$ & $68.3 \mathrm{a}$ \\
10 & 72 & $177.7 \mathrm{a}$ & $23.7 \mathrm{~b}$ \\
\hline
\end{tabular}

${ }^{\mathrm{z}}$ Data on callus growth and SEs/g were recorded after 4 weeks and $60 \mathrm{~d}$, respectively.

${ }^{y}$ Means with different letters within the same column and belonging to the same inhibitor concentration are significantly different at $P=0.05$ according to Tukey's test. Means are the averages of 20 replicates (plates) per treatment and per duration. The experiment was repeated twice at different times. 
counted from five pairs of guard cells in each of the three leaf samples for a total of 15 pairs of guard cells per plant.

\section{Results and Discussion}

Effect of colchicine and oryzalin on callus growth and somatic embryogenesis. After 4 weeks, callus production increased in all media (Tables 1 and 2). For colchicine, callus increase rate was highest for callus exposed to $2.5 \mathrm{~mm}$ colchicine, regardless of exposure time, but callus growth rate dropped as colchicine concentration and/or exposure time increased for the rest of the media (Table 1). These results were consistent with several other studies, including those with carrots (Daucus spp. L.), poinsettias (Euphorbia pulcherrima Willd. ex Klotzsch), and Watsonia lepida N. E. Brown (Ascough et al., 2008; Pickens et al., 2006; Sloan and Camper, 1981). Callus production slightly increased (compared with the control media) and remained generally constant in culture media containing 30 or $60 \mu \mathrm{M}$ oryzalin, regardless of exposure time, but steadily

Table 2. Callus growth (\%) and number of somatic embryos/g callus (SEs/g) from Hedychium muluense callus exposed to various concentrations of oryzalin for various durations. ${ }^{\mathrm{z}}$

\begin{tabular}{cccc}
\hline Concn $(\mu \mathrm{M})$ & Exposure time $(\mathrm{h})$ & Percent callus growth $^{\mathrm{y}}$ & Number of SEs/g callus $^{\mathrm{y}}$ \\
\hline 0 & 24 & $397.1 \mathrm{a}$ & $81.5 \mathrm{a}$ \\
0 & 48 & $396.2 \mathrm{a}$ & $77.7 \mathrm{a}$ \\
0 & 72 & $391.3 \mathrm{a}$ & $78.7 \mathrm{a}$ \\
30 & 24 & $421.8 \mathrm{a}$ & $234.4 \mathrm{a}$ \\
30 & 48 & $467.9 \mathrm{a}$ & $244.7 \mathrm{a}$ \\
30 & 72 & $453.0 \mathrm{a}$ & $245.1 \mathrm{a}$ \\
60 & 24 & $478.5 \mathrm{ab}$ & $96.8 \mathrm{a}$ \\
60 & 48 & $462.4 \mathrm{ab}$ & $99.6 \mathrm{a}$ \\
60 & 72 & $597.9 \mathrm{a}$ & $95.3 \mathrm{a}$ \\
120 & 24 & $602.9 \mathrm{a}$ & $90.5 \mathrm{a}$ \\
120 & 48 & $412.3 \mathrm{~b}$ & $89.2 \mathrm{a}$ \\
120 & 72 & $339.6 \mathrm{~b}$ & $91.3 \mathrm{a}$ \\
\hline
\end{tabular}

${ }^{\mathrm{z}}$ Data on callus growth and SEs/g were recorded after 4 weeks and $60 \mathrm{~d}$, respectively.

${ }^{y}$ Means with different letters within the same column and belonging to the same inhibitor concentration are significantly different at $P=0.05$ according to Tukey's test. Means are the averages of 20 replicates (plates) per treatment and per duration. The experiment was repeated twice at different times.

declined over time for medium containing $120 \mu \mathrm{M}$ oryzalin (Table 2). The results indicated that both oryzalin and colchicine promoted callus production at lower concentrations. The decline in callus growth when colchicine concentration or exposure time was increased can be attributed to the higher toxicity level of colchicine compared with oryzalin. Similar results were obtained when shoot tips of the ornamental Alocasia micholitziana 'Green Velvet' were treated with colchicine or oryzalin (Thao et al., 2003).

For somatic embryo production, there was a marked difference between colchicine and oryzalin (Tables 1 and 2 ). There was little variation among media containing $0,2.5$, or $5 \mathrm{~mm}$ colchicine, but the longer exposure times had a clear inhibitory effect on embryo production in medium containing $10 \mathrm{~mm}$ colchicine (Table 1). Both higher concentrations and longer exposure times to colchicine have been reported to adversely affect somatic embryo production in cork oak anther cultures (Pintos et al., 2007). On the other hand, media containing 0,30 , or $120 \mu \mathrm{M}$ oryzalin produced similar numbers of embryos per gram of callus,regardless of exposure time, but the most noticeable result here was the dramatic increase in somatic embryo production obtained in media containing $30 \mu \mathrm{M}$ oryzalin (Table 2), implying that promotion of somatic embryogenesis in $H$. muluense using oryzalin was mostly dose-dependent. Rey
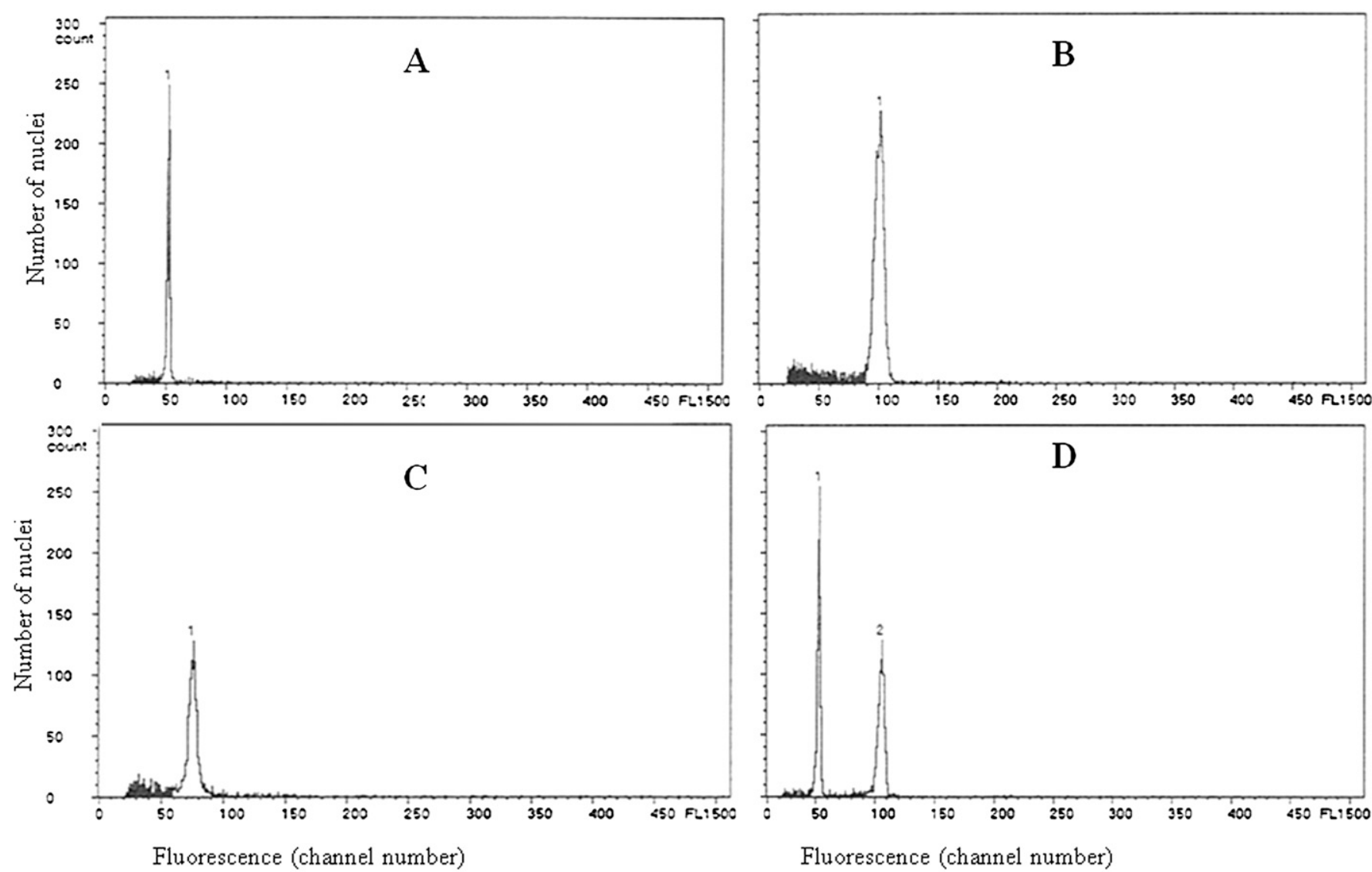

Fig. 1. Histogram of relative DNA content of nuclei isolated from diploid (A), tetraploid (B), triploid (C), and mixoploid (D) of Hedychium muluense leaves. Diploid (control) nuclei were set to channel 50 with triploids resolving at channel 75 and tetraploids resolving at channel 100. 
et al. (2002) have suggested that stimulation of somatic embryogenesis by antimitotic agents may be related to the induction or synthesis of stress proteins. Higher oryzalin concentrations have been reported to have an inhibitory effect on somatic embryo production (Pintos et al., 2007), but no such effect was found with the concentrations used in the current study.

Flow cytometric analysis of ploidy level. Ploidy level of control, colchicine- and oryzalin-treated samples was successfully determined using flow cytometry as illustrated by representatives of histograms showing diploid $(2 x)$, tetraploid $(4 x)$, triploid $(3 x)$, and mixoploid $(2 \mathrm{x}+4 \mathrm{x})$ (Fig. 1A-D). Flow cytometry analysis has proven to be a rapid and efficient method for estimating the ploidy levels of the colchicine- and oryzalin-treated regenerated plants. It was particularly suited in this study because of the large number of samples that needed to be analyzed. Also, because young tissues, which have lower concentration of starch, polysaccharides, and other metabolites than in older tissues (Lee and Lin, 2005), from recently regenerated plants were used, the values of the coefficients of variation obtained were generally lower than 2.0, indicating the reliability of the results.

Stomatal frequency and length. Mean stomatal frequency per square millimeter, stomatal length, and the number of chloroplasts per guard cell were calculated. For stomatal frequency per square millimeter, ANOVA revealed significant differences among leaf samples collected from diploid, triploid, and tetraploid plants (Table 1). The stomatal frequency in diploid plants was 1.5 and 1.8 times greater than that observed in triploid and tetraploid plants, respectively. There was no overlap among diploid, triploid, and tetraploid plants. Stomatal frequency and ploidy were inversely related as confirmed by the highly significantly negative correlation coefficient $(r=-0.74, P=0.001)$ between the two parameters. These results are in agreement with those reported by others (Beck et al., 2003; Sapra et al., 1975; Tan and Dunn, 1973). The results obtained in this study clearly demonstrated that stomatal frequency differed markedly among diploid, triploid, and tetraploid $H$. muluense plants and that this characteristic can be used to determine the ploidy of this species. For stomatal length, there was a significant difference between diploid and triploid plants on the one hand and diploid and tetraploid plants on the other $(P=0.05)$; however, no statistical difference $(P=0.05)$ was found between triploid and tetraploid plants (Table 1).

Chloroplast counts. There were significant differences $(P=0.05)$ among diploid, triploid, and tetraploid plants (Table 3; Fig. 2A-B), indicating that ploidy level can be separated based on chloroplast number per pair of guard cells. There was no overlap between any two of these means, and ploidy level and chloroplast numbers were highly positively correlated $(r=0.70, P=0.001)$. Our results were in agreement with previously published reports on other plant species (Beck et al., 2003; Sari et al., 1999; Singsit and Ozias-Akins, 1992; Singsit and Veilleux, 1991). Qin and Rotino (1995) found that chloroplast number in guard cells represented a more reliable and consistent indicator of ploidy in anther-derived pepper plants compared with stomatal cell length and attributed this difference to the fact that chloroplast number is more stable than the size of stomata, which may be more influenced by age and leaf position.

Chromosome counts. Conventional chromosome staining $(0.2 \%$ Azure B) was used to count the chromosome number from cell spreads and determine the ploidy level of $H$. muluense, which was found to be diploid $(2 n=2 x=34)$ (Fig. 2C). This is the first report on the ploidy status of this species. Chromosome count was also used to confirm the ploidy inferred by other methods (Figs. 1B and 2D).

Effect of colchicine and oryzalin on polyploidization. No spontaneous polyploidization occurred because all control plants tested were diploid, but polyploidy was induced in both colchicine- and oryzalincontaining cultures (Tables 4 and 5). The four types of polyploids obtained included

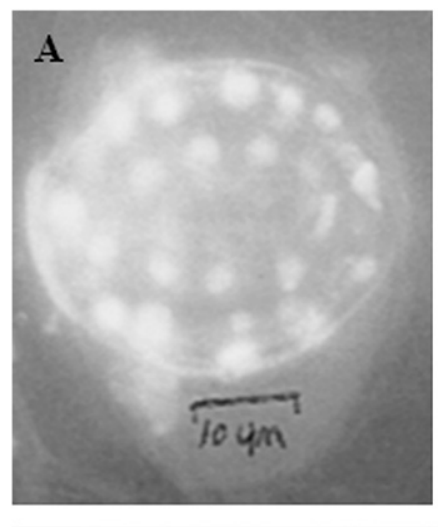

B

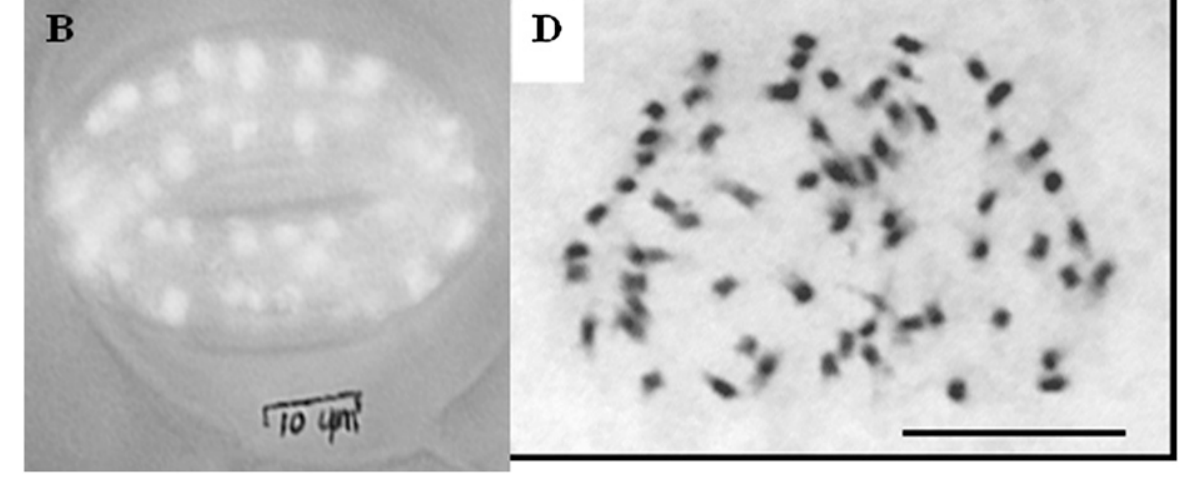

triploid (3x), tetraploid (4x), and mixoploid $(2 \mathrm{x}+4 \mathrm{x}$ and $3 \mathrm{x}+4 \mathrm{x})$. Interestingly, no mixoploid consisting of $2 \mathrm{x}+3 \mathrm{x}$ was obtained in any of the two antimitotic treatments (Tables 4 and 5). For colchicine, the $2.5 \mathrm{~mm}$ concentration was generally more efficient at inducing polyploidy, regardless of exposure time, but more tetraploid plants were obtained when the cultures were exposed to this concentration for $24 \mathrm{~h}$ (Table 4). Polyploidization efficiency declined for media containing $5 \mathrm{~mm}$ colchicine. Although cultures containing 10 $\mathrm{mm}$ colchicine produced somatic embryos (Table 1), no plants from this treatment were tested because the embryos failed to convert into fully developed plants. High concentrations of colchicine have been associated with plant cell death because of the highly toxic effect of this antimitotic agent, which blocks spindle fiber development and modifies the differentiation process (Eeckhaut et al., 1955; Pintos et al., 2007). This toxicity is in part attributable to the generally higher colchicine concentrations needed for polyploidy induction because colchicine binds poorly to plant tubulins (Morejohn et al., 1987).
Fig. 2. Guard cells showing 22 and 31 chloroplasts per pair of guard cells for a diploid plant (A) and induced tetraploid plant (B), respectively. Somatic chromosome spreads of $H$. muluense stained with $0.2 \%$ Azure B: (C) diploid $(2 n=2 x=34)$ cell and (D) tetraploid $(2 n=2 x=68)$ cell. Bar for chromosome spreads is $10 \mu \mathrm{m}$.

Table 3. Mean stomatal frequency and length and chloroplast number per pair of guard cells from diploid, triploid, and tetraploid Hedychium muluense plants regenerated from somatic embryos.

\begin{tabular}{lccc}
\hline Ploidy & Stomatal frequency $/ \mathrm{mm}^{2}$ & Stomatal length $(\mu \mathrm{m})$ & Chloroplast number \\
\hline Diploid & $54.0 \pm 0.4 \mathrm{a}^{\mathrm{z}}$ & $31.6 \pm 0.5 \mathrm{~b}$ & $22.8 \pm 0.1 \mathrm{c}$ \\
Triploid & $37.0 \pm 1.2 \mathrm{~b}$ & $44.0 \pm 0.7 \mathrm{a}$ & $25.1 \pm 0.2 \mathrm{~b}$ \\
Tetraploid & $30.8 \pm 0.3 \mathrm{c}$ & $45.0 \pm 0.9 \mathrm{a}$ & $29.0 \pm 0.3 \mathrm{a}$ \\
\hline
\end{tabular}

${ }^{\mathrm{z}}$ Means \pm SE with different letters within the same column are significantly different at $P=0.05$ according to Tukey's test. 
Table 4. Effect of colchicine concentration and exposure time on polyploidization of in vitro regenerated Hedychium muluense plants.

\begin{tabular}{lccccccc}
\hline & & & & & \multicolumn{2}{c}{ Mixoploid } \\
\cline { 3 - 7 } Concn $(\mathrm{mm})$ & Duration $(\mathrm{h})$ & Totalplants tested & Diploid & Triploid & Tetraploid & $2 \mathrm{x}+4 \mathrm{x}$ & $3 \mathrm{x}+4 \mathrm{x}$ \\
\hline 0 & 24 & 100 & 100 & 0 & 0 & 0 & 0 \\
0 & 48 & 100 & 100 & 0 & 0 & 0 & 0 \\
0 & 72 & 100 & 100 & 0 & 0 & 0 & 0 \\
2.5 & 24 & 100 & 81 & 3 & 13 & 2 & 1 \\
2.5 & 48 & 100 & 89 & 2 & 7 & 1 & 1 \\
2.5 & 72 & 100 & 88 & 2 & 6 & 3 & 1 \\
5 & 24 & 100 & 97 & 1 & 2 & 0 & 0 \\
5 & 48 & 100 & 98 & 0 & 2 & 0 & 0 \\
5 & 72 & 100 & 99 & 0 & 1 & 0 & 0 \\
\hline
\end{tabular}

Table 5. Effect of oryzalin concentration and exposure time on polyploidization of in vitro regenerated Hedychium muluense plants.

\begin{tabular}{cccccccc}
\hline & & & & & \multicolumn{2}{c}{ Mixoploid } \\
\cline { 5 - 7 } Concn $(\mu \mathrm{M})$ & Duration $(\mathrm{h})$ & Total plants tested & Diploid & Triploid & Tetraploid & $2 \mathrm{x}+4 \mathrm{x}$ & $3 \mathrm{x}+4 \mathrm{x}$ \\
\hline 0 & 24 & 100 & 100 & 0 & 0 & 0 & 0 \\
0 & 48 & 100 & 100 & 0 & 0 & 0 & 0 \\
0 & 72 & 100 & 100 & 0 & 0 & 0 & 0 \\
30 & 24 & 100 & 87 & 3 & 6 & 2 & 2 \\
30 & 48 & 100 & 81 & 5 & 9 & 2 & 3 \\
30 & 72 & 100 & 83 & 2 & 12 & 1 & 2 \\
60 & 24 & 100 & 82 & 3 & 12 & 2 & 1 \\
60 & 48 & 100 & 80 & 2 & 13 & 2 & 3 \\
60 & 72 & 100 & 78 & 3 & 15 & 3 & 1 \\
120 & 24 & 100 & 83 & 2 & 13 & 1 & 1 \\
120 & 48 & 100 & 83 & 3 & 10 & 2 & 2 \\
120 & 72 & 100 & 87 & 1 & 9 & 1 & 2 \\
\hline
\end{tabular}

Fully developed plants were obtained in all oryzalin-containing media, including those containing higher concentrations (Table 2), which can be explained by the less toxic effect of oryzalin as compared with colchicine (Pintos et al., 2007). Moreover, because of its higher affinity for plant tubulin, oryzalin is used at lower concentrations in chromosome duplication studies (Bajer and Molè-Bajer, 1986; Hugdahl and Morejohn, 1993). Oryzalin was effective in inducing polyploidy at all concentrations used in this study. The best result was obtained when cultures were exposed to $60 \mu \mathrm{M}$ oryzalin for $72 \mathrm{~h}$. The percentages of induced tetraploidy increased for $30 \mu \mathrm{M}$ and $60 \mu \mathrm{M}$ oryzalin as the exposure time increased, but this percentage decreased for $120 \mu \mathrm{M}$ oryzalin as exposure time increased (Table 2). Overall, our results showed that oryzalin was more efficient in inducing polyploidy, in particular tetraploidy, than colchicine, a result that is in agreement with a number of recent reports (De Ascough et al., 2008; Carvalho et al., 2005; Dhooghe et al., 2009; Eeckhaut et al., 2004; Viehmannová et al., 2009). Furthermore, colchicine is highly toxic to humans because of its affinity to microtubules of animal cells (Morejohn et al., 1987). Therefore, oryzalin can be used as a valid and safer alternative to colchicine for inducing polyploidy in $H$. muluense.

\section{Conclusion}

Flow cytometry analysis, chloroplast counts, and stomatal frequency were very effective in assessing the ploidy of diploid and polyploid $H$. muluense plants. All these methods were confirmed by the cytological preparation of somatic chromosome spread. Although stomatal size correctly separated the tetraploid and triploid on the one hand and the diploid on the other, it was less effective in distinguishing the tetraploid and triploid plants (Table 1). However, this method can be complementary with flow cytometry to describe periclinal chimeras arisen through the action of mitosis inhibitors. It is worth mentioning that stomata only yield information on the LI layer unlike roots, which provide information on the LIII layer and leaves on the LI + LII layers for monocots and LI + LII + LIII layers for dicots. Furthermore, in the absence of flow cytometry, chloroplast count and/or stomatal frequency could be used to assess the ploidy in $H$. muluense. The current study established an efficient polyploidization method for $H$. muluense. The induction of dwarf polyploid, particularly tetraploid, $H$. muluense plants could help remove the hybridization barrier resulting from ploidy differences. This could pave the way for the development of more dwarf and compact Hedychium plants (which are preferred by consumers) through the hybridization of the induced tetraploid $H$. muluense plants with some of the more ornamentally attractive but tall tetraploid Hedychium plants.

\section{Literature Cited}

Aryavand, A., B. Ehdaie, B. Tran, and J.G. Waines. 2003. Stomatal frequency and size differentiate ploidy levels in Aegilops neglecta. Genet. Resources Crop Evol. 50:175-182.

Ascough, G.D., J.E. Erwin, and J. van Staden. 2008. Effectiveness of colchicine and oryzalin at inducing polyploidy in Watsonis lepida N. E. Brown. HortScience 43:2248-2251.

Bajer, A.S. and J. Molè-Bajer. 1986. Drugs with colchicine-like effects that specifically disassemble plant but not animal microtubules. Proc. N. Y. Acad. Sci. 466:767-784.

Beck, S.L., R.W. Dunlop, and A. Fossey. 2003. Stomatal length and frequency as a measure of ploidy in black wattle, Acacia mearnsii (de Wild). Bot. J. Linn. Soc. 141:177-181.

Bonos, S.A., K.A. Plumley, and W.A. Meyer. 2002. Ploidy determination in Agrostis using flow cytometry and morphological traits. Crop Sci. 42:192-196.

Dansi, A., H.D. Mignouna, M. Pillay, and S. Zok. 2001. Ploidy variation in the cultivated yams (Dioscorea cayenensis-Dioscorea rotundata complex) from Cameroon as determined by flow cytometry. Euphytica 119:301-307.

De Carvalho, J.F.R.P., C.R. de Carvalho, and W.C. Otoni. 2005. In vitro induction of polyploidy in annatto (Bixa orellana). Plant Cell Tiss. Org. Cult. 80:69-75.

Dhooghe, E., S. Denis, T. Eeckhaut, D. Reheul, and M.-C. Van Labeke. 2009. In vitro induction of tetraploids in ornamental Ranunculus. Euphytica 168:33-40.

Eeckhaut, T.G.R., S.P.O. Werbrouck, L.W.H. Leus, E.J. Van Bockstaele, and P.C. Debergh. 2004. Chemically induced polyploidization in Spathiphyllum wallisii Regel through somatic embryogenesis. Plant Cell Tiss. Org. Cult. 78:241-246.

Eigsti, D.I. and P. Dustin. 1995. Spindle and cytoplasm. pp. 65-139. In Colchicine in Agriculture, Medicine, Biology and Chemistry. The Iowa State College Press, Ames, IA.

Eeckhaut, T.G.R., S.P.O. Werbrouck, L.W.H. Leus, E.J. Van Bockstaele, P.C. Eigsti, D.I. and P. Dustin. 1955. Spindle and cytoplasm, p. 65-139. In: Agriculture. The Iowa State College Press, Ames, IA.

Eksomtramage, L., P. Sirirugsa, P. Jivanit, and C. Makoni. 2002. Chromosome counts of some Zingiberaceous species from Thailand. Songklanakarin J. Sci. Technol. 24:312-319.

Gao, L., N. Liu, B. Huang, and X. Hu. 2008. Phylogenetic analysis and genetic mapping of Chinese Hedychium using SRSp markers. Scientia Hort. 117:369-377.

Gopanraj, G., M. Dan, S. Shiburaj, M.G. Sethuraman, and V. George. 2005. Chemical composition and antibacterial activity of the rhizome oil of Hedychium larsenii. Acta Pharm. 55: 315-320.

Hugdahl, J.D. and L.C. Morejohn. 1993. Rapid and reversible high affinity binding of the dinitroaniline herbicide oryzalin to tubulin from $\mathrm{Zea}$ mays L. Plant Physiol. 102:725-740.

Jewel, D.C. and N. Islam-Faridi. 1994. A technique for somatic chromosome preparation and $\mathrm{C}$ banding of maize, p. 484-493. In: Freeling, M. and V. Walbot (eds.). The maize handbook. Springer-Verlag, New York, NY.

Lee, H. and T. Lin. 2005. Isolation of plant nucleir suitable for flow cytometry from recalcitrant tissue by use of a filtration column. Plant Mol. Biol. Rpt. 23:53-58.

Lehrer, J.M., M.H. Brand, and J.D. Lubell. 2008. Induction of tetraploidy in meristematically active seeds of Japanese barberry (Berberis thunbergii var. atropurpurea) through exposure to colchicine and oryzalin. Scientia Hort. 119:67-71.

Morejohn, L.C., T.E. Bureau, J. Molè-Bajer, A.S. Bajer, and D.E. Fosket. 1987. Oryzalin, adinitroaniline herbicide, binds to plant tubulin and inhibits microtubule polymerization in vitro. Planta 172:252-264. 
Mukherjee, I. 1970. Chromosome studies of some species of Hedychium. Bot. Mag. Tokyo. 83: 237-241.

Pickens, K.A., Z.M. Cheng, and S.A. Kania. 2006. Effect of colchicine and oryzalin on callus and adventitious shoot formation of Euphorbia pulcherrima 'Winter Rose'. HortScience 41: 1651-1655.

Pintos, B., J.A. Manzanera, and M.A. Bueno. 2007. Antimitotic agents increase the productivity of double-haploid embryos from cork oak anther culture. J. Plant Physiol. 164:15951604.

Qin, X. and G.L. Rotino. 1995. Chloroplast number in guard cells as ploidy indicator of in vitrogrown androgenic pepper plantlets. Plant Cell Tiss. Org. Cult. 41:145-149.

Raghavan, T.S. and K.R. Venkatasubban. 1943. Cytological studies in the family Zingiberaceae with special reference to chromosome number and cyto-taxonomy. Proc. Indian Acad. of Sci. Ser. B 47:352-358.

Rajendra, B.R., K.A. Mujeeb, and L.S. Bates. 1978. Relationships between 2x Hordum sp., $2 \mathrm{x}$ Secale sp. and $2 \mathrm{x}, 4 \mathrm{x}, 6 \mathrm{x}$ Triticum $\mathrm{sp}$. for stomatal frequency, size and distribution. Environ. Exp. Bot. 18:33-37.

Rey, H.Y., P.A. Sanberro, M.M. Collavino, J.R. Davina, A.M. Gonzales, and L.A. Mroginski. 2002. Colchicine, trifluralin, and oryzalin promoted development of somatic embryos in Ilex paraguariensis (Aquafoliaceae). Euphytica 123: 45-46.
Risso-Pascotto, C., M.S. Pagliarini, and C.B. do Valle. 2005. Multiple spindles and cellularization during microporopgenesis in an artificially induced tetraploid accession of Brachiaria ruziziensis (Gramineae). Plant Cell Rpt. 23: 522-527.

Sakhanokho, H.F., R.Y. Kelley, and K. Rajasekaran. 2008. First report of plant regeneration via somatic embryogenesis from shoot apexderived callus of Hedychium muluense R. M. Smith. J. Crop Improv. 21:191-200.

Sapra, V.T., J.L. Hughes, and G.C. Sharma. 1975. Frequency, size and distribution of stomata in Triticale leaves. Crop Sci. 15:356-358.

Sari, N., K. Abak, and M. Pitrat. 1999. Comparison of ploidy level screening methods in waremelon: Citrulus lanatus (Thunb.). Matsum. \& Nakai. Scientia Hort. 82:265-277.

SAS Institute. 2003. SAS 9.1.3. SAS Institute, Inc., Cary, NC.

Sharma, A.K. and N.K. Bhattacharyya. 1958. Cytology of several members of Zingiberaceae and a study of the inconstancy of their chromosome complements. Cellule 59:301346.

Singsit, C. and P. Ozias-Akins. 1992. Rapid estimation of ploidy levels in in vitro-regenerated interspecific Arachis hybrids and fertile triploids. Euphytica 64:183-188.

Singsit, C. and R.E. Veilleux. 1991. Chloroplast density in guard cells of leaves of antherderived potato plants grown in vitro and in vivo. HortScience 26:592-594.
Sloan, M. and N.D. Camper. 1981. Effects of colchicine on carrot callus - Growth and status. Plant Cell Tiss. Org. Cult. 1:69-75.

Takamura, T. and I. Miyajima. 1996. Colchicine induced tetraploids in yellow-flowered cyclamens and their characteristics. Scientia Hort. 65:305-312.

Tan, G.Y. and G.M. Dunn. 1973. Relationship of stomatal length and frequency and pollen-grain diameter to ploidy level in Bromus inermis Leyss. Crop Sci. 13:332-334.

Teare, I.D., C.J. Peterson, and A.G. Law. 1971. Size and frequency of leaf stomata in cultivars of Triticum aestivum and other Triticum species. Crop Sci. 11:496-498.

Thao, N.T.P., K. Ureshino, I. Miyajima, Y. Ozaki, and H. Okubo. 2003. Induction of tetraploids in ornamental Alocasia through colchicine and oryzalin treatments. Plant Cell Tiss. Org. Cult. 72:19-25.

Viehmannová, I., E.F. Cusimamani, M. Bechyne, M. Vyvadilová, and M. Greplová. 2009. In vitro induction of polyploidy in yacon (Smallanthus sonchifolius). Plant Cell Tiss. Org. Cult. 97:21-25.

Wood, T.H., W.M. Whitten, and N.H. Williams. 2000. Phylogeny of Hedychium and related genera (Zingiberaceae) based on ITS sequence data. Edinb. J. Bot. 57:261-270.

Yamaguchi, M. 1989. Basic studies on the flower color breeding of carnation (Dianthus caryophyllus L.). Bull. F. Hort. Minmikyushu Univ. 19:1-78 [in Japanese with English summary]. 